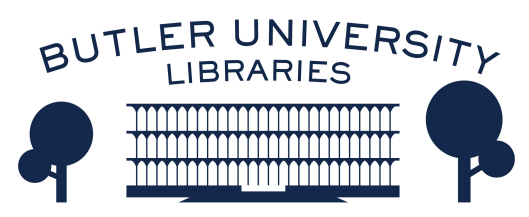

Journal of Hindu-Christian Studies

Volume 22

Article 10

January 2009

\title{
Ramanuja and Schleiermacher On Language: Comparative Theology for Constructive Theology
}

Jon Paul Sydnor

Follow this and additional works at: https://digitalcommons.butler.edu/jhcs

Part of the Religion Commons

\section{Recommended Citation}

Sydnor, Jon Paul (2009) "Ramanuja and Schleiermacher On Language: Comparative Theology for Constructive Theology," Journal of Hindu-Christian Studies: Vol. 22, Article 10.

Available at: https://doi.org/10.7825/2164-6279.1437

The Journal of Hindu-Christian Studies is a publication of the Society for Hindu-Christian Studies. The digital version is made available by Digital Commons @ Butler University. For questions about the Journal or the Society, please contact cbauman@butler.edu. For more information about Digital Commons @ Butler University, please contact digitalscholarship@butler.edu. 


\title{
Ramanuja and Schleiermacher On Language: Comparative Theology for Constructive Theology
}

\author{
Jon Paul Sydnor \\ Emmanuel College
}

THE truth of the Veda is affirmed in the aphorism, 'The relation of words to facts is natural [autpattika: inherent, original, primordial] (Mimamsa Sutras I.I.7)'. Just as fire and water do naturally possess their properties like heat, just as the senses like sight and hearing are naturally productive of particular kinds of cognition, words also have a natural power of imparting knowledge. ${ }^{1}$

The whole work of the Redeemer Himself was conditioned by the communicability of His self-consciousness by means of speech, and similarly Christianity has always and everywhere spread itself solely by preaching. Every proposition which can be an element of the Christian preaching (kerygma) is also a doctrine, because it bears witness to the determination of the religious selfconsciousness as inward certainty ... Thus this communication is, on the one hand, something different from the piety itself, though the latter cannot, any more than anything else which is human, be conceived entirely separated from all communication. But, on the other hand, the doctrines in all their forms have their ultimate ground so exclusively in the emotions of the religious self-consciousness, that where these do not exist the doctrines cannot arise. ${ }^{2}$

\section{Introduction}

If comparative theology is to produce constructive theology, then must that resulting constructive theology be syncretistic? This question may very well prove to be consequential for the future of comparative theology. If comparative theology can prove itself to be methodologically potent in theological construction, then this utility will legitimate its practice. However, if comparative theology is solely able to produce syncretistic constructive theology, then the practice of comparative theology will be limited to those who are open to such syncretism. This audience may prove to be small. If so, then comparative theology may never integrate with the broader theological world.

A second option may be available. If comparative theology can produce discrete, nonsyncretistic constructive theology, then the use of this potent method may expand dramatically, as it would include those who might shy away from syncretism. The purpose of this paper is to

Jon Paul Sydnor is currently Assistant Professor of Comparative Theology at Emmanuel College in Boston. He has a BA in English and Philosophy from the University of Virginia, an MDiv and ThM from Princeton Theological Seminary, and a $\mathrm{PhD}$ in Systematic and Comparative Theology from Boston College where he trained with Francis X. Clooney, Terrence N. Tice, S. Mark Heim, and Michael J. Himes. His dissertation compares Ramanuja and Schleiermacher on the doctrine of absolute dependence, attempting to produce constructive theology from the questions produced through comparative theology. He has published on Vaishnavism in the Journal of Vaishnava Studies, Jacques Dupuis' theology of religions in International Review of Mission, and on interreligious cognition and comparative visual theology in Studies in Interreligious Dialogue. He has presented or responded at the American Academy of Religion, International Schleiermacher Society, Engaging Particularities conferences, Catholic Mission Forum, and Society for Comparative Theology (Boston). Dr. Sydnor is also ordained in the United Church of Christ, and co-pastors a church with his wife, Rev. Abby Henrich. 
explicitly demonstrate the discrete or nonsyncretistic constructive potential of comparative theology. It will do so by placing two theologians - the Srivaisnava Ramanuja and the Reformed/Lutheran Schleiermacher-into conversation with each other on the subject of language. In so doing, the paper will demonstrate that comparative theology has the potential to produce constructive theology. Moreover, this constructive theology need not be syncretistic.

In demonstrating this possibility we recognize that, in certain theological quarters, an allergy to syncretism already exists. Nevertheless, in this paper no allergy to syncretism is being prescribed. Indeed, judicious syncretism may very well be an appropriate constructive move. The purpose of this paper is definitively not to establish the uselessness, superfluity, or even ancillary nature of comparative constructive theology. The purpose of this paper is to demonstrate that an interreligious dialectic can further theologies along their pre-existing trajectories, along parallel paths that need not converge. In other words, post-comparative theology may be discretely constructed. The paper will conclude that comparative theology can advance religious thought either syncretistically or discretely, according to the disposition of the comparativist and her target audience.

\section{Comparison}

Schleiermacher and Ramanuja have pronouncedly divergent doctrines of language. For Ramanuja, Sanskrit is eternal. As eternal, it is uncreated by Brahman but preserved through periods of dissolution and re-creation in the mind of Brahman. Sanskrit is the means of creation itself, and as such Sanskrit imprints reality with its own grammar, rendering creation and Sanskrit unitary in structure. For Schleiermacher, all language is a historical phenomenon, changing from place to place and from time to time. Language is not the medium of creation; it is an aspect of creation. Indeed, Schleiermacher deems the "Mosaic" (Hebrew) account of creation-which, in Genesis Chapter One, is mediated by language - to be irrelevant to the feeling of absolute dependence, and hence irrelevant to dogmatics. ${ }^{3}$ (This dismissal is not due to the divine use of language, but due to the presentation of creation as an event in time rather than the eternal preservation of the cosmos.)

Because Schleiermacher deems language to be an aftermath of creation, he sees no correlation between the grammar of any language and the grammar of reality. Ramanuja, asserting such a correlation, " subordinates religious consciousness to language. $\mathrm{He}$ asserts that the consciousness of the Vedantin is to be structured by the Sanskrit of the Veda, as augmented by auxiliary texts such as the dharmasastras, itihasas, and puranas. $^{4}$ Schleiermacher disagrees, subordinating language to the religious consciousness. He asserts that the unarticulated Christian consciousness is possessed of tremendous language-forming potential which culminates in dogmatic theology.

This distinction has enormous implications for the respective missiologies of Ramanuja and Schleiermacher. For Schleiermacher, the feeling of absolute dependence upon our God who is love is inherently translatable into any culture in any time and any place. The Christian Godconsciousness is, if you will, a content without form. It must be granted form through the culture in which it manifests itself. ${ }^{5}$ This manifestation can occur through any culture. In fact, so perfectly translatable is this content that no culture is to be preferred over any other culture, and no language is to be preferred over any other language. Christ's consciousness is as articulable in $19^{\text {th }}$ century Germany as it is in $1^{\text {st }}$ century Palestine, in German as it is in Aramaic. Indeed, Christ's consciousness is as articulable in Tamil as it is in Sanskrit. For Schleiermacher, the feeling of absolute dependence is plastic, assuming the form of whatever culture it encounters. ${ }^{6}$

Ramanuja's Brahman-consciousness, if we may call it that, does not share the plasticity of Schleiermacher's God-consciousness. Instead, for Ramanuja, the consciousness of the moksapara (seeker of liberation) must be Sanskritized. So, this consciousness can only be manifested through one linguistic form rather than many linguistic forms. Ramanuja's valuation of Sanskrit is a result of, and dovetails 
with, his holistic exegesis of the Veda. Ramanuja retains the karma kanda, or ritual portion of the Veda, and the jnana kanda, or knowledge portion of the Veda, as necessary but ancillary adjuncts to the bhakti kanda, or devotional portion of the Veda. Crucially, these rituals and this knowledge are in Sanskrit and cannot be translated. That is, analogous sentences in other languages will of necessity lack the salvific phenomenological import of the Sanskrit. ${ }^{7}$

While later Visistadvaitins may have asserted that these three kandas could be bypassed by means of prapatti, there is no explicit allowance for such a circumvention in Ramanuja's own work. Quite the contrary, there is prescribed a multifaceted devotional practice which prepares the moksapara to receive moksa (release). And this preparation involves the inculcation of Sanskritic "mental impressions" (samskaras) preserved from beginningless time. ${ }^{8}$ Only Sanskrit has an inherent relation to reality, both spiritual and material. Therefore, only Sanskrit vocabulary in Vedic word order generates those "mental impressions" which are preparatory to release. For this reason, the release-seeking consciousness must be Sanskritized. No other language will serve.

While neither Ramanuja nor Schleiermacher allow for contradictions in their theological systems, both present different understandings of the problem of contradiction. For Ramanuja, any contradiction in the scriptures must be apparent rather than real, since scripture is derived immediately from Brahman, from whom no contradiction could appear. These contradictions can be resolved through the application of reason to all relevant scriptural passages, by which means all contradictions can be resolved in one holistic exegesis. ${ }^{9}$ Schleiermacher believes that contradictions are symptomatic of poetic and rhetorical forms of Christian expression which are so occasional as to lack systematic precision. These contradictions can be resolved through the collocation of poetic, rhetorical, and Christ's own expressions into one rigorous system of "descriptively didactic" doctrine-or, in other words, a dogmatic. ${ }^{10}$

Several other issues are raised through the comparison of Ramanuja and Schleiermacher's doctrines of language. For one, a comparative reading of Ramanuja's doctrine of Sanskrit as eternal calls into question Schleiermacher's attempt to stabilize temporal German through dialectic and systematization, without reference to any abiding verbal meaning. Ramanuja also recognizes the instability of everyday, historical words, as he notes the difference in definition between Sanskritic words in their Vedic context and the same words in everyday use. However, his solution to the challenge of historical language is more radical. $\mathrm{He}$ ascribes to scripture an eternal meaning which is accessible through rigorous exegetical practice. Successful exegesis requires intensive, sequential study of the Veda (Purva Mimamsa first, then Uttara Mimamsa), a learned guru, study of the Puranas and other texts which expound the Veda, and the activation of all acquired knowledge through upasana, or devotional meditation. In this way, the inherent meaning of Vedic words in Vedic sentences can be discerned, which will stimulate a phenomenal experience which, activated through devotional meditation, leads to salvation. ${ }^{11}$

In contrast, Schleiermacher's understanding of language as historical, coupled with his demand of a fixed meaning for words, seems problematic. Although Schleiermacher never explicitly describes language as a historical phenomenon, that he understood it to be so seems a legitimate inference from his highly historical understanding of human thought. Indeed, Schleiermacher defines dogmatic theology as "the science which systematizes the doctrine prevalent in a Christian Church at a given time."12 From this statement we may infer that (within certain parameters) dogmatic theology, as well as its vocabulary, will be different in different places at different times. This variability obtains despite the invariable feeling of absolute dependence upon our God who is love that underlies all Christian feeling and hence, all Christian theology. While implicitly asserting the historical nature of language, Schleiermacher also asserts both the need to and the possibility of stabilizing a word's meaning through placing it in dialectical relationship with other words, within the context of a coherent system of theological propositions. 
Problems arise when we consider twin characteristics of Schleiermacher's doctrine of language, which may very well be exclusive. To begin, Schleiermacher's concept of dogmatics necessitates a dialectical linguistics within a system of propositions which is self-contained (abgeschlossen: sēcluded, solitary, enclosed). ${ }^{13}$ Dogmatics is to comprise a complete system (Vollstandigkeit des Lehrgebaudes) ${ }^{14}$ that provides an absolute context (in einem absoluten Zusammenhang $)^{15}$ for all propositional language, thereby establishing a perfectly definite relation among them (unter ihnen vollkommen bestimmt sind). ${ }^{16}$ This self-containment we may deem the "introverted" character of Schleiermacher's theology. That is, in order to be perfectly precise and perfectly stable, it must be perfectly selfreferential. The finitude of the internal referents, coupled with the vast number of their mutual relations, generates a fixed system in which each referent is defined, directly or indirectly, by every other referent. And through this system meaning becomes precise, stable, and scientific.

But at the same time, Schleiermacher also prescribes an "extroverted" theology. $\mathrm{He}$ specifically states in the Glaubenslehre's Introduction that dogmatics will eagerly seek to utilize the language of ethics, philosophy of religion, apologetics, psychology, etc. in order to discuss how religious feeling becomes diversified and what object it refers to. In other words, dogmatics will borrow the scientific terminology of these realms in order to more precisely express itself. His own Introduction does not qualify as dogmatics, under Schleiermacher's own definition, because it is not a disclosure of the specifically Christian consciousness. Nevertheless, in order to introduce his dogmatics Schleiermacher borrows propositions from ethics, philosophy of religion, apologetics, and psychology.

Problematically, Schleiermacher is borrowing vocabulary from outside his finite, self-contained system. But such borrowing opens up the system to vocabulary which is no longer fixed through definite relationship. The introduction of any one term which is not fixed by relation will, of necessity, destabilize the entire system. Thus the tension between Schleiermacher's introverted need for a finite, fixed, precise terminology and extroverted need for borrowed scientific terminology seem to be at odds. It is not that faith and science are at odds; Schleiermacher would eschew any tension between faith and science, and much of his program is directed toward resolving that perceived tension. But there is a tension between the static nature of perfectly stable dogmatic language and the dynamic nature of investigative scientific language. Within this context, any stability one might achieve will be but momentary, and momentary stability is oxymoronic.

Schleiermacher himself notes this danger, as he notes that changes in philosophical language often result in changes in dogmatic language. ${ }^{17}$ It is possible that external vocabulary is borrowed first, and then stabilized through incorporation into the system. But the ongoing life of the term outside of the system will still threaten any fixed definition. Even "absolute contexts" have contexts within the realm of language and culture. This observation only raises the tension between scientific precision and linguistic dynamism. Dogmatics must adapt to history, and dogmatics must be exact. But historical dynamism precludes perfect precision.

If historical language is, in fact, an imperfect medium of religious communication, then Schleiermacher faces a more profound problem. He specifically states that "the whole work of the Redeemer Himself was conditioned by the communicability of His self-consciousness by means of speech [Rede], and similarly Christianity has always and everywhere spread itself solely by preaching [Verkündigung]. ${ }^{.18}$ In other words, Christ effects redemption through the communication (Mitteilung) of his sinless perfection. $^{19}$ But perfection would seem to necessitate a perfect medium for communication. Incongruously, Schleiermacher does not ascribe this perfection, or its possibility, to language. While Schleiermacher notes that communication also occurs through gesture and countenance, the centrality of preaching renders speech fundamental to religious communication.

With reference to individuals, Schleiermacher states that "the discovery of this differentiating 'matter [between individuals] in any individual existence is a task which can never be perfectly, but only approximately, discharged in words and sentences. $" 20$ But if 
Christ cannot perfectly distinguish himself from imperfect human beings, then by what means can his perfection be discerned? Since his selfconsciousness was originally conveyed by nontechnical, non-dogmatic, imperfect speech, then how was the perfection of his self-consciousness mediated by the imperfection of that form of language? Insofar as such questions cast doubt on the possibility of redemption, they threaten to undermine Schleiermacher's entire dogmatic system.

To a certain extent, this point is moot. After all, the power of language to communicate redemption is ratified by Christ's use of language, not Schleiermacher's doctrine of language. ${ }^{21}$ However, at this point it is not clear that Schleiermacher's doctrine of language dovetails with Christ's legitimation of language. A comparative reading of Ramanuja and Schleiermacher on this point suggests that clarification is needed; comparison has presented a constructive opportunity. However, Schleiermacher would not likely turn to Ramanuja's "magical" doctrine of language in order to resolve any contradiction within his own. We might expect instead a more naturalistic approach. Perhaps he would indeed deem stability to be but momentary, or define perfect stability as a goal to be approached asymptotically. Whatever the reconciliation, the postulated constructive response to Ramanuja's challenge would not likely be syncretistic given Schleiermacher's own concerns about "alien" (fremd: foreign, strange, external) influences. (Again, this is Schleiermacher's position, not the position of this essay.)

Another interesting point of contact arises between Ramanuja and Schleiermacher. We noted above that due to the assertion of consonance between Sanskrit and reality, Ramanuja is able to make linguistic arguments with ontological consequences. For example, he argues that because language is differentiated, and because differentiated language describes Brahman, then Brahman must be differentiated. ${ }^{22}$ Schleiermacher, like the Advaitins, ascribes simplicity to God. ${ }^{23}$ But he offers a very different interpretation, closer to the Srivaisnava position, insofar as he defines simplicity as "the unseparated and inseparable mutual inherence of all divine attributes and activities."24 Nevertheless, we may be tempted to ask based on reading Ramanuja: can Schleiermacher ascribe such simplicity to God by means of differentiated language?

It would appear as if Schleiermacher is not bound to address this question, since he does not share Ramanuja's linguistic ontology. That is, arguments cannot be made from the nature of language to the nature of reality for two reasons. First, Schleiermacher's dogmatics is not concerned with the objective nature of reality but with the felt experience of salvation. Second, Schleiermacher ascribes no ontological acumen to language. It simply does not have the primordial generativity that Ramanuja's Sanskrit has, and is therefore not a cipher for the nature of the universe or of the divine.

However, Schleiermacher may also question Ramanuja on the relationship between divinity and language. Ramanuja describes Brahman as eternal. ${ }^{25}$ At the same time, Ramanuja asserts the reliability of Vedic language as a means of knowledge (pramana) of Brahman. And as noted above, he asserts that because language is differentiated, Brahman must be differentiated rather than undifferentiated, as the Advaitins would claim. But we can also note that language is temporal. Words occur in time. At the precise moment that a word such as "eternal" (nitya) ${ }^{26}$ is being spoken, at the center of that moment, part of the word lies in the past, part in the present, and part in the future. "Eternal". describes Brahman, but as a spoken word it is divided by time. Therefore, according to Ramanuja's doctrine of language, we could plausibly infer that Brahman must be divided by time. But Brahman cannot be divided by time, because Brahman is eternal. This (possible) quandary may present a challenge to contemporary Srivaisnava theologians. If so, then comparison has produced another constructive opportunity. Yet again, Srivaisnava theologians would not likely respond to this challenge through any adoption of Schleiermacher's naturalistic doctrine of language. Instead, they would more likely look to their own resources, perhaps postulating an eternal form of language, of which temporal language is but a manifestation. In any event, their response to the Schleiermachian challenge would be wholly Srivaisnava, rather than Schleiermachian. 
Finally, the comparison of our two theologians raises interesting questions regarding hermeneutics, stability, and precision. As noted above, both theologians ask to what degree precise language is necessary for successful religious communication. In the end, both Ramanuja and Schleiermacher demand precision, although in very different ways. Schleiermacher attempts to establish technically precise language within a historical framework, without reference to eternal, abiding meanings. Ramanuja, on the other hand, asserts the eternal meaning of Vedic words in Vedic word order.

Oddly, this eternal meaning generates an exceptionally dynamic exegetical tradition. Srivaisnava scriptural interpretation changes over time. For Srivaisnavism, does this dynamism suggest error and its correction, or can change reflect the continuous development of an originally authentic yet insufficiently articulated exegetical impulse (in accordance with Schleiermacher's understanding of the development of doctrine through time)? In other words, could Schleiermacher's treatment of doctrinal development assist Srivaisnavas in justifying their own exegetical dynamism? For our purposes, answering such questions would necessitate excessive speculation. In speculative areas such as these, it is best to allow traditions to speak for themselves. Nevertheless, once again comparison has produced an opportunity for discrete construction. Were Srivaisnavas to utilize Schleiermacher's concept of doctrinal development in order to explain their own exegetical dynamism, then only minor adaptation would be necessary. This aspect of Schleiermacher's thought could be incorporated into Srivaisnava thought, leaving it (possibly) more articulate yet wholly faithful to the preexisting Srivaisnava theological trajectory.

Ramanuja and Schleiermacher produce vastly different linguistics. Nevertheless, their comparison across a vast expanse of space and time has proven fruitful. New questions have arisen through our comparison, questions which might otherwise have lain dormant. We have elicited latent aspects of each theologian. In other words, Ramanuja and Schleiermacher have spoken differently in inter-religious dialogue than either would have spoken in intra-religious dialogue.
This outcome is extremely consequential. The generation of a question is a precious event, for it allows the possibility of an answer. New questions generate new answers, and new answers constitute constructive theology. So comparative theology, if fruitfully executed, inevitably leads to constructive theology. Additionally, this constructive theology need not be syncretistic (although it may legitimately be so, if this is the disposition of the constructivist). We have not had the space or presumptiveness, in this essay, to answer the new questions. However, we have demonstrated that the questions generated through comparison can be answered from the tradition's own resources, without resorting to syncretism. This utility is consequential - it may expand the practice of comparative theology beyond its current confines into those theological quarters which are less comfortable with explicit syncretism. The methodological potency of comparative theology for constructive theology has therefore been demonstrated, be it discrete (as in this case) or syncretistic.

\section{Notes}

1 Ramanuja. Vedarthasamgraha. S.S. Raghavachar, transl. Mysore: Sri Ramakrishna Ashrama, 1956. Para. 227, page 177. "The relation of words to facts is natural." Skt: autpattikastu sabdasyarthena sambandhah. Van Buitenen translates: "Meaning is inherent in the word." Van Buitenen, J.A.B. Ramanuja's Vedarthasamgraha: Introduction, Critical Edition and Annotated Translation. Pune: Deccan College Postgraduate and Research Institute, 1992. Brahmavadin translates: "The relationship of a word with its meaning is indeed eternal." The Brahmavadin: A Fortnightly Religious and Philosophical Journal. Madras: Thompson and Company, 1896-1912. Vols. 1.1 through 17.8. Raghavachar's term "natural" represents a loose translation, and does not mean "derived from nature." "Autpattika" literally means "original," or "from/at the beginning." In other words, the universal form of the object does not precede its appellation, although the universal form and the appellation do precede any particular object. So, because universal form and appellation are eternally cognate, meaning is more primordial than natural: "The relationship 
38 Jon Paul Sydnor

between the word and its meaning is primordial."

Schleiermacher, Friedrich. The Christian Faith. Trans. by H. R. Mackintosh and J. S. Stewart. Edinburgh: T \& T Clark, 1999. §15.2, 77-78.

${ }^{3}$ The Christian Faith. $\$ 40.3,151$.

${ }^{4}$ Vedarthasamgraha. $\$ 232-233,180-181$.

${ }^{5}$ The Christian Faith. $\$ 15.2,77$.

${ }^{6}$ cf. Lamin Sanneh. Translating the Message: The Missionary Impact on Culture. New York: Orbis Books, 1989. 197-207.

${ }^{7}$ Vedarthasamgraha. $\S 127,99-100$. Ramanuja's Srivaisnava tradition later came to regard Tamil as a second language of revelation, thereby diminishing the need for a Sanskritized consciousness.

${ }^{8}$ Vedarthasamgraha. Van Buitenen translation. $\S 139,233$. See also Brahmavadin. §231, 677. Here, samskara is translated as "innate impressions."

${ }^{9}$ Vedarthasamgraha. $\$ 277,177$.

${ }^{10}$ The Christian Faith. $\S 18.2,86$.

11 Ramanuja. Brahma-Sutras: Sri Bhasya. Swami Vireswarananda and Swami Adidevananda, transl. Calcutta: Advaita Ashrama, 1995. §1.1.1, 1-3.

${ }_{12}$ The Christian Faith. $\$ 19$ (Proposition), 88.

${ }^{13}$ The Christian Faith. $\$ 20$ (Proposition), 94.

${ }^{14}$ The Christian Faith. $\$ 18.3,87$.

${ }^{15}$ The Christian Faith. $\$ 28.2,120$.

${ }^{16}$ The Christian Faith. \$28.2, 120.

${ }^{17}$ The Christian Faith. $\$ 19$ (Postscript), 93.

${ }^{18}$ The Christian Faith. $\$ 15.2,77$.

${ }^{19}$ The Christian Faith. $\S 88$ (Proposition), 361.

${ }^{20}$ The Christian Faith. $\$ 10.3,47$.

${ }^{21}$ The Christian Faith. $\$ 15.2,77$.

${ }^{22}$ Vedarthasamgraha. $\S 19,20-21$.

${ }^{23}$ The Christian Faith. $§ 96.1,392$.

${ }^{24}$ The Christian Faith. $\S 56.1,231$.

${ }^{25}$ Vedarthasamgraha. \$157, 126-127.

${ }^{26}$ Vedarthasamgraha. $\$ 157,125-127$. Brahman is characterized as nitya, or eternal. 